REMÉNYI, Judit

\title{
Always-on in Higher Education - Embedded Use of Mobile Technologies at BME
}

\section{Introduction}

Higher education is undergoing an economic and a pedagogical crisis: It is increasingly treated as an economic resource and commodity, its relevance is increasingly expressed in economic terms, and is in the focal point of numerous changes such as spending cuts, increasing tuition fees, heavier reliance on ICT to drastically change the student experience, and the need for complete renewal content, teaching and learning wise. In this hopefully great revival of learning, mobile technologies ${ }^{1}(\mathrm{MT})$ could be given a central role.

\section{The global problem of higher education}

After centuries of unquestioned and unchanged patterns of university education, more and more education professionals, academics and students are crying for transformation. The students' general lack of satisfaction with higher education manifests itself among others in early school leaving, giving up higher education prematurely, transferring to other courses, poor academic performance; although, "success in higher education is vital for jobs, productivity and growth"2. "Currently, too many students in the EU drop out before they complete their higher education degree. Students from a lower socio-economic background and other disadvantaged groups are the most likely to drop out", although it could be prevented in most cases. The case is not different at Budapest University of Technology and Economics (BME) either.

Obviously, there is not a single reason for early school leaving and poor academic performance, but the "business" is urging a revolutionary approach towards designing and delivering higher education courses and programmes relying on innovative delivery technologies and integrating students' performance boosting solutions. No doubt, cuttingedge delivery technologies without the support of massive pedagogical paradigm shift will not sustain the higher education status quo. T. Hixon, investor and Forbes contributor says "Higher education is now ground zero for disruption" and adds that "History teaches that productivity increase usually does happen, driven by innovation, especially in information businesses such as education. When it happens it is likely to be disruptive for institutions that believe it will not happen." ${ }^{3}$. "Blended courses, online learning, and MOOCs are moving at light speed compared to the typical university." ${ }^{4}$ Hailing the change will not be sufficient;

\footnotetext{
${ }^{1}$ The term mobile technologies is used in the paper to mean smart phones, iPads, tablet computers, but not laptops and notebooks.

${ }^{2}$ http://www.nesetweb.eu/sites/default/files/HE\%20Drop\%20out\%20AR\%20Final.pdf

${ }^{3}$ http://www.forbes.com/sites/toddhixon/2014/01/06/higher-education-is-now-ground-zero-for-disruption/

${ }^{4}$ Lucas, H.: Disrupting and Transforming the University. http://cacm.acm.org/magazines/2014/10/178788disrupting-and-transforming-the-university/fulltext
} 
we need to prepare for it by "reinventing" ${ }^{5}$ higher education, reconfiguring mainstream university education. The reinvention must result in a fundamentally altered learning experience. Class time should be devoted to more efficient ways of learning such as problem solving, discussion, interactive, cooperative activities, as for example in "flipped classes".

\section{The relationship of higher education and technology}

Historically, higher education failed to have a technological core, but online learning meant a breakthrough in this respect. Online courses, blended learning, MOOCs ${ }^{6}$ have been disrupting higher education. "The established players, if history is any guide, will try to preserve their model as long as possible by making it a hybrid or a blended model where we teach in our classrooms and then we augment that with online resources-but without much doing, online learning will just supplant in classroom learning." 7

Initially, enthusiasm was running high, online courses were increasingly found to "provide efficient and timely access to learning materials" ${ }^{8}$ for students who are pushed into higher education by their parents still seeing extraordinary value in university education but needed more cost effective solutions. However, dissatisfaction with online learning is growing now as online courses are found to "deliver instructions without influencing students' achievements" ${ }^{\prime \prime}$.

So it might be stated that in spite of all our efforts, simply deploying state-of-the-art technology cannot do the trick. Although e-learning technologies were widely accepted as an effective addition to the traditional learning theory, the quality of teaching and learning practices has not been essentially improved." ${ }^{10}$ So, we still need to squeeze the maximum number of students into lecture halls and exam-marking rosters ${ }^{11}$ and are trying to do our best to keep the students motivated and provide them positive learning experiences. However, since Christensen coined the phrase disruptive innovation, an increasing number of those concerned with higher education have been discussing the disruptive effect of information and communication technologies on higher education. Its danger is even more obvious with the penetration rates of mobile technologies.

In the lack of a mobile tool specifically designed for education, in the following we focus on mobile devices ${ }^{12}$ as a potential new "candidate" for altering university student experience. Mobile technologies can fulfill most of not all criteria of a disruptive innovation as they are products and services first taking root in simple applications at the bottom of the

\footnotetext{
${ }^{5}$ Mehafy, G.: The Disruption of Higher Education.

http://www.edtechmagazine.com/higher/article/2012/07/facing-changing-times-higher-education

${ }^{6}$ Lucas, H.: Disrupting and Transforming the University. http://cacm.acm.org/magazines/2014/10/178788disrupting-and-transforming-the-university/fulltext\#T2

7 Christensen, C.:The disruption of higher education. An interview by The Economist Intelligence Unit 2013. http://facultyecommons.org/disruption-higher-education/

8 Milner, E.:Students' Development in the Digital Age: Intellectual Freedom or Frivolity?

http://www.ninjaessays.com/blog/students-development-in-the-digital-age-intellectual-freedom-or-frivolity/

${ }^{9}$ Milner, E.:Students' Development in the Digital Age: Intellectual Freedom or Frivolity? http://www.ninjaessays.com/blog/students-development-in-the-digital-age-intellectual-freedom-or-frivolity/

${ }^{10}$ Milner, E.:Students' Development in the Digital Age: Intellectual Freedom or Frivolity?

http://www.ninjaessays.com/blog/students-development-in-the-digital-age-intellectual-freedom-or-frivolity/

${ }^{11}$ http://www.economist.com/blogs/freeexchange/2014/02/online-education

${ }^{12}$ Mobile devices include smartphones, tablet PCs, and iPads, but not laptops or notebooks.
} 
market and then moving up market and displacing established competitors ${ }^{13}$. "There is considerable interest in exploiting the almost universal appeal and abundance of these technologies for their educational use." ${ }^{14}$ The educational capabilities of the new devices are driven by their technical capabilities. "These new capabilities inspire new practices which can lead to valuable outcomes, but, to date, application of theory to the use of these technologies for educational purposes is lacking." 15

In spite of the EU strategies, initiatives for mobile learning in formal education, "the practice of using mobile phones for education is still emergent" ${ }^{16}$ in the EU as national ministries of education seem to lack interest and awareness. Neither national guidelines, nor instructional materials are available for enthusiastic teachers, although mobile learning already began in the 1980s in Europe. Integrating mobile technologies into classroom education might be a solution for decreasing drop-out rates and increasing student performance.

\section{The Hungarian situation}

In 2014, the drop-out rate in Hungarian higher education was $35 \% .{ }^{17}$ Varga, J. says that the drop-out rate in Hungarian higher education was $45 \%$ in $2010 .{ }^{18}$ It should be noted that high drop-out rates, switching to other university courses are international problems. "Students dropping out during just the first year of their degree are now running at an all-time high." ${ }^{19}$

Faculty experience and education statistics ${ }^{20}$ suggest that Generation Z students are not finding standard lecture courses interesting and motivating enough in Hungary either. While students drop out due to several reasons such as: academic factors, social factors, change of intention, motivation, and attitudes, organizational changes, and background changes ${ }^{21}$; the practice of extending university studies instead of completing the course in three years, which is a typical phenomenon in Hungarian higher education, can be more directly linked to academic factors. These students most likely have the least academic approach to their studies to get through examinations. In other words, we might say that their dissatisfaction and failure is more often than not due to the fact that we cannot provide them with effective and sustainable learning experiences. Furthermore, we do not seem to have a structured pedagogical approach to solve the problem or a viable alternative to the traditional teaching / learning system.

\footnotetext{
${ }^{13}$ http://www.claytonchristensen.com/key-concepts/\#sthash.qdNB2fkn.dpuf

${ }^{14}$ Literature Review in Mobile Technologies and Learning http://www2.futurelab.org.uk/resources/documents/lit_reviews/Mobile_Review.pdf

${ }^{15}$ Literature Review in Mobile Technologies and Learning http://www2.futurelab.org.uk/resources/documents/lit_reviews/Mobile_Review.pdf

${ }^{16}$ Turning on Mobile Learning in Europe. Illustrative Initiatives and Policy Implications

${ }^{17}$ http://mno.hu/belfold/igy-lehet-megakadalyozni-a-lemorzsolodast-1259682

${ }^{18}$ Varga, J.:Mennyit ér a diploma a kétezres években Magyarországon ?

www.hier.iif.hu/hu/letoltes.php?fid=tartalomsor/1987

${ }^{19}$ http://www.dailymail.co.uk/news/article-2122591/More-fifth-university-students-fail-finish-degree.html

${ }^{20}$ http://observatory.org.hu/csokken-az-iskolai-lemorzsolodas-europaban-a-diplomasok-szama-pedig-nomagyarorszagon-nem-ilyen-jo-a-helyzet/

${ }^{21}$ Molnár, B.: A felsőoktatásban tapasztalható lemorzsolódás lehetséges okai http://www.slideshare.net/molnarbea/molnr-beta-lemorzsolds-tanulmny
} 


\section{The present MT use related situation at BME}

The learning environment of higher education in Hungary can still be characterized by the one-size-fits-all traditional approach of top-down, often authoritative, one-to-one lecture driven content transfer. In other words, although digital technologies have been fast changing the way we learn, they do not change the way how students are taught at Hungarian universities. Despite the kind of conservative approach of numerous Budapest University of Technology and Economics (BME) faculty members, they observe that the majority of the students bring their own mobile devices and use them during classes even if that is often discouraged or even forbidden. That is, mobile media consumption is becoming mainstream at the University, although, as experience suggests the use of MT is less frequent for taking notes in the classroom than for other purposes. It implies a considerable pedagogical challenge for the faculty such as how to avoid the distracting effects of in-class digital media use or how to avoid the destructive effect of in-class social media use. Furthermore, it raises serious pedagogical issues such as that of balance between fun and hard work in learning, that of digital technologies related skill development instead of content provision, that of enabling collaborative learning and performance assessment instead of individualized solutions etc. There seems to be a relationship between the students' digital learning skills and the faculty's suggested use of digital technologies. Digital technology based new modes of learning are however not yet a reality at the University (and the situation is similar at other Hungarian universities as well).

Literature shows that educators worldwide "have considered harnessing these devices within and beyond the classroom" (Mueller et al. 2012) as they are transforming young people's learning habits and related expectations as well. Nevertheless, Hungarian higher educational institutions tend to be still failing to recognize the urgent demand for thorough changes. Although it is widely recognized - by faculty members also - that mobile technology has great potential for educational use, the following approach is still "mainstream":

"A university classroom. The instructor is reading aloud from a passage in the assigned work for the week. He looks up to find his students all deeply engrossed.

Their rapture, alas, is not with him but with their laptop screens, their attention worlds away

Later that day, the professor fires off an email to his colleagues suggesting that laptops be banned from the classroom because of incidents like this."

(Davidson - Goldberg, 2010)

BME faculty members tend to have three strategies concerning the use of mobile technology, more or less similarly to their colleagues' strategies worldwide:

- Encouraging the use of MT. Having recognized the educational potentials of mobile technology and its prominence in the students' life, the followers of this strategy not only encourage the use, but also devise plans how to integrate the use of mobile technology into mainstream education to make incentive, collaborative, participatory learning reality. It should be noted that the encouraged use should be based on 
preplanned pedagogical activities directing student attention on coursework related issues.

- $\quad$ Restricting the use of MT. Although it is a fact that students are far from paying full attention to the lectures, they are repeatedly engaged in some other activities such as googling, reading, etc. Digital technology is seen to compete with faculty for the students' attention thus is considered to be a major distracter. Frequently switching their attention back and forth - from listening to a lecture to using their MT for some non-class related activities can result in poor learning. - In this case the fact that students' behaviour and expectations have much changed is not properly taken into consideration.

As at present there is no commonly agreed theory of how to best use mobile devices to customize learning, faculty members will need to experiment with innovative solutions, appropriate for the nature of the course. It is obvious that it is a long way until we will be able to avoid the traps of misusage resulting in adverse effects.

- Tolerating the use of MT. Since most faculty members might belong to this category, for different reasons such as recognizing the educational potential of digital technology but not knowing how to harness it, or lacking the stamina to restrict the use, maybe not wanting to loose their popularity etc. It is necessary to persuade them to change their strategies and utilize MT for their own interest and for their students' benefit.

At the University there is no explicit policy on the in-class use of mobile technology except for phoning in-class and the use of MT in examinations, which is prohibited. Most faculty members tolerate their use, but it disturbs them, e.g. because of the distraction of attention. Once mobile technologies have reached the higher educational institutions, instead of restricting or tolerating their use, we should encourage and integrate them in the classrooms. However, it takes a long way to change approaches and strategies and use them confidently and efficiently. At present it seems that this kind of innovation and experimentation is not being fueled. Still, inspirations may come from the faculty's low satisfaction with their own pedagogical performance.

\section{The research}

The research, started in May 2014, is carried out at the Department of Technical Education, BME. The Department provides MA courses for engineer-teachers and economist-teachers and also numerous part-time postgraduate courses for teachers. Faculty members have gained invaluable first-hand experience of students' in-class MT use. Since the average "classroom size" varies from 12 to 50, it is possible to pay attention to the students' non-classwork related activities. Since the Department provides English language courses for foreign students, their patterns of MT use can be compared to those of Hungarian students. The observations and the urgent need for changing our strategies and methodologies have led us to design and start the research.

The goal of the research is to find out whether there are dominant patterns of in-class mobile technology use at BME, that is:

- What mobile devices students use, 
- How often they tend to use MT in ninety-minute classes, that is whether they are light or heavy media users, and

- What purposes they use MT for.

International survey findings provide some information on the global situation; however, there are considerable differences among nations due to their characteristics and differences of cultures. The differences concern - among others - the way how often Hungarians tend to use their MT, what they use them for, their authority respect etc. What is evident is that Hungarians are "talkers", tending to discuss anything in public aloud. Furthermore, Hungarian youngsters tend to obsessively use social media to have their own voice, to be "insiders" in a community and follow strong communication-related patterns. A recent Hungarian survey has found that $83 \%$ of the respondents $(1,000$ persons) use social sites. Another Hungarian survey reports that the number of Facebook users increased by half a million in a year and totaled in three millions. My experience suggests that Hungarian students respect authority more than foreign peers, as non-encouraged in-class use of MT in the first (few) week(s) of the course is not characteristic for Hungarian students.

The hypotheses of the research are:

- The great majority of the students at BME bring MT into class.

- Students at BME use their MT several times in class in a non-encouraged way.

- Students at BME use the MT for non-academic purposes more often than for academic purposes in class.

- The majority of the faculty members at BME do not encourage the in-class use of MT.

\section{The stages of the research}

The stages of the research are:

- Surveying Hungarian and international students doing different courses at the University by using a short questionnaire of close questions concerning the patterns of their MT use,

- Interviewing teachers about their readiness to integrate mobile technology into their classes,

- Designing models of integrating MT into lectures taking into consideration dominant educational cultures, specific course/programme characteristics, teacher preferences etc.,

- Analysis of the results and producing recommendations concerning the optimum inclass use of MT.

A paper based survey was chosen since it was essential for the students to complete the questionnaire immediately at the end of the ninety-minute lecture, when they may not have forgotten how they had used their devices.

\section{Preliminary results of the survey}

The survey of students started in May 2014 and is still in progress. The first results suggest that: 
- The use of smart phones can be considered general, while i-Pads, e-Readers, tablets are used sporadically. Foreign students seem to be better equipped with MT than their Hungarian peers. The enhanced affordability will certainly increase the rate, consequently we need to prepare for the general use.

- Almost as many respondents use mobile technology (MT) for academic purposes as for non-academic purposes in class. Those who report using MT for academic purposes use it for checking online dictionaries (foreign students, Hungarian students doing a course in foreign language or studying foreign language), checking course related information (such as course requirements, deadlines etc.), accessing outside resources, taking notes, taking photos and recording. However, almost half of the respondents report using MT for reading and writing text messages and using social networking websites. The increasing volume and the improving quality of online information may further encourage the non-encouraged in-class use. At the same time social changes might further increase the importance of "staying connected to a social site". Consequently the use of MT for non-academic purposes will also increase.

- The respondents use MT at least 1-3 times during a ninety-minute class, but almost as many respondents report that they use them 4-8 times. MT frequency of use indicators will obviously not decrease or stagnate, so we either can devise "checkingin", "sharing location" related pedagogical activities or need to get used to this kind of distraction.

- A great majority of the respondents report that they think MT will change education. This should be well understood and become common goal of faculty members. However, it should preferably be supported by findings on in-class use patterns related surveys and systematic planning and design.

In a similar survey, Kinash found that "mobile phones appear to be used mainly for nonacademic (off task) activities with students reporting that $80 \%$ of mobile use was dedicated to social networking, 75\% for web browsing and 68\% for email". (Kinash et al., 2011) It is obvious that mobile devices polarize student activity in any learning environment, some only use MT for class-related purposes, while at least as many students use MT for non-class related activities as well.

\section{Conclusion}

As the preliminary results show that the majority of the students bring their own MT devices and use them in class, it is obviously necessary to experiment with innovative approaches to integrate the use into traditional lectures as well. No doubt - as surveys and empirical experience suggest - the in-class use of mobile devices in lectures may increase interactivity, and the different ways of in-class use of mobile devices allow for a personalized educational experience. Furthermore, the encouraged in-class use of MT - leading the students to reach sooner digital media consumption saturation point (global survey findings suggest that our digital media consumption is increasing) - can have a positive effect on student attention, consequently on learning. The use of MD in a university environment can be an added value and an incentive as well. The mode and frequency of the use can be defined after the survey has been finished and the results analysed, since the mainstream patterns of nonencouraged in-class usage should be considered when designing tomorrow's university education at BME. 
Knowing the high penetration of mobile devices on the BME campus, we argue that mobile technologies should not be ignored as part of the learning environment and experience. There are two ways of integrating MD into university instruction: either students will work out for themselves how to use them for their learning, or faculty by understanding and accepting the limitations of mobile technologies and studying whether mobile applications are suitable for a given purpose, make sensible decisions about how to use them ${ }^{22}$.

The use of mobile devices at universities can be beneficial both for students and faculty. On the one hand it can enable students to:

- stay productive in lectures,

- access the learning management system of the university and access course-related information,

- take notes and structure and organize them and later restructure them,

- share notes and use them anytime and anywhere,

- have access to faculty provided class materials,

- have access to extra content,

- view visual images,

- look up cases, statutes,

- use online dictionaries,

- use electronic learning resources.

On the other hand it can enable faculty to:

- transferring information,

- directly support the learning process,

- divide lecture-type classes into several micro learning units and provide feedback to each,

- intensively engage students and keep them involved,

- personalize the learning environment and the learning path,

- encourage collaborative learning,

- (more or less) satisfy students' need for media consumption,

- prevent students' multitasking,

- keep students off of social media sites,

- (radically) decrease MT related distraction to others.

We argue that pedagogical innovation is being pushed by new mobile technologies extending the boundaries of teaching and learning. Consequently, mainstream patterns and modes of university education should be rethought and development strategies of MT integration should be formulated, and methodologies should be developed taking into consideration increasingly diverse learner backgrounds, in terms of prior knowledge, learning needs, learning strategies, dominant media consumption customs etc. This way our efforts might result in a quality twenty-first century higher education model.

\footnotetext{
${ }^{22}$ Armatas, Ch., Holt, D., and Rice, M.: Balancing the possibilities for mobile technologies in higher education
} 


\section{References:}

1. Christensen, C.: The disruption of higher education. An interview by The Economist Intelligence Unit 2013.

http://facultyecommons.org/disruption-higher-education/

2. Davidson, C., Goldberg, D. (2010) The Future of Thinking. Learning Institutions in a Digital Age. The MIT Press.

3. Kemp, S. (2014) Social, Digital \& Mobile Worldwide in 2014 , http://wearesocial.net/blog/2014/01/social-digital-mobile-worldwide-2014/

4. Lucas, H.: Disrupting and Transforming the University. http://cacm.acm.org/magazines/2014/10/178788-disrupting-and-transforming-theuniversity/fulltext

5. Mehafy, G.: The Disruption of Higher Education. http://www.edtechmagazine.com/higher/article/2012/07/facing-changing-times-highereducation

6. Milner, E.: Students' Development in the Digital Age: Intellectual Freedom or Frivolity? http://www.ninjaessays.com/blog/students-development-in-the-digital-age-intellectualfreedom-or-frivolity/

7. Mueller, J., Wood, E., Pasquale, D., Cruikshank, K. (2012) Students learning with mobile technologies in and out of the classroom. http://www.formatex.info/ict/book/414420.pdf

8. Robinson, J. (2014) Digital media consumption is eating our time, ttp://pando.com/2014/02/10/digital-media-consumption-is-eating-our-time/

9. Vidékiné Reményi, J. (2014) Patterns of Non-encouraged In-class Mobile Technologies Use at Budapest University of Technology and Economics (BME). EDEN Research Workshop.

10. Zhu, E., Kaplan, M., Dershimer, R. C., \& Bergom, I. (2011) Use of laptops in the classroom: Research and best practices (No. 30). CRLT Occasional Papers. Center for Research on Teaching and Learning: University of Michigan. http://teachingcenter.wustl.edu/Journal/Reviews/Pages/Research-In-ClassDevices.aspx\#.VBF1X60KWnQ

11. Literature Review in Mobile Technologies and Learning http://www2.futurelab.org.uk/resources/documents/lit_reviews/Mobile_Review.pdf

12. http://inklingmedia.net/2014/03/17/11-reasons-people-love-social-media2/\#.VB_bQleDHFw

13. http://www.marketing112.hu/a-15-24-eves-fiatalok-kozossegiportal-hasznalati-szokasai1-resz/

14. http://psprovocative.com/kozossegi-elet-facebookon-tul/

15. http://www.origo.hu/techbazis/20130614-kutatas-a-magyar-internethasznalatiszokasokrol.html

16. http://www.theguardian.com/education/2012/nov/27/should-mobiles-be-bannedschools

17. http://www.edudemic.com/mobile-devices-in-the-classroom-2/ 
18. http://www.statista.com/chart/2169/growth-of-average-time-spent-per-day-withmajor-media/

19. http://www.pqmedia.com/about-press-20130812.html

20. http://blog.britishcouncil.org/2014/05/19/how-students-can-use-their-mobile-phonesto-learn-english/

21. http://ascilite.org.au/ajet/submission/index.php/AJET/article/viewFile/589/1064w

22. https://www.thetrumpet.com/article/11237.32552.161.0/the-real-problem-with-highereducation

23. The Future of Higher Education in Europe. http://www.Ise.ac.uk/europeanInstitute/LEQS/LEQSPaper50.pdf

24. http://www.researchinlearningtechnology.net/index.php/rlt/article/view/19184/0

25. http://www.slideshare.net/molnarbea/molnr-beta-lemorzsolds-tanulmny

26. http://www.digitaleurope.org/Ourwork/BoostingDigitalGrowth/Transformingeducation. aspx\#maincontent 